\title{
Natural Occurrence of Ochratoxin A in Spices Marketed in the Czech Republic during 2019-2020
}

\author{
Darina Pickova ${ }^{1, *(\mathbb{D})}$, Jakub Toman ${ }^{1, * \mathbb{D}}$, Vladimir Ostry ${ }^{1,2} \mathbb{D}$ and Frantisek Malir ${ }^{1} \mathbb{D}$ \\ 1 Department of Biology, Faculty of Science, University of Hradec Kralove, Rokitanskeho 62, \\ CZ-50003 Hradec Kralove, Czech Republic; ostry@chpr.szu.cz (V.O.); frantisek.malir@uhk.cz (F.M.) \\ 2 Center for Health, Nutrition and Food in Brno, National Institute of Public Health in Prague, Palackeho 3a, \\ CZ-61242 Brno, Czech Republic \\ * Correspondence: darina.pickova@uhk.cz (D.P.); jakub.toman@uhk.cz (J.T.); \\ Tel.: +420-722-049-025 (D.P.); +420-607-154-471 (J.T.)
}

Citation: Pickova, D.; Toman, J.; Ostry, V.; Malir, F. Natural Occurrence of Ochratoxin A in Spices Marketed in the Czech Republic during 2019-2020. Foods 2021, 10, 2984 https://doi.org/10.3390/ foods10122984

Academic Editors: José Bernal del Nozal and Ana M. Ares

Received: 19 October 2021

Accepted: 29 November 2021

Published: 3 December 2021

Publisher's Note: MDPI stays neutral with regard to jurisdictional claims in published maps and institutional affiliations.

Copyright: (c) 2021 by the authors. Licensee MDPI, Basel, Switzerland. This article is an open access article distributed under the terms and conditions of the Creative Commons Attribution (CC BY) license (https:/ / creativecommons.org/licenses/by/ $4.0 /)$.

\begin{abstract}
Spices are a popular ingredient in cuisine worldwide but can pose a health risk as they are prone to fungal infestation and mycotoxin contamination. The purpose of this study was to evaluate ochratoxin A (OTA) in 54 single-kind traditional and less traditional spices, each of which was purchased in six samples of different batches (324 samples in total) at the Czech market during 2019-2020. The HPLC-FLD method with pre-treatment by immunoaffinity columns was employed to determine OTA. The limits of detection and quantification were $0.03 \mathrm{ng} \mathrm{g}^{-1}$ and $0.10 \mathrm{ng} \mathrm{g}^{-1}$, respectively. A total of 101 (31\%) samples of 19 spice kinds were positive at concentrations ranging from $0.11-38.46 \mathrm{ng} \mathrm{g}^{-1}$. Only turmeric was contaminated with an OTA level exceeding the European Union limits. However, most spices have no regulation, thus further extensive monitoring of various mycotoxins in various kinds of spices is necessary. Chilli and black pepper are the most studied spices for OTA contamination, however, many other kinds of spice can also be highly contaminated, but studies on them are less common, rare, or have not yet been performed. The uniqueness of this study lies in the wide range of spice types studied for the presence of OTA on the Czech market.
\end{abstract}

Keywords: spices; ochratoxin A; immunoaffinity columns; HPLC-FLD

\section{Introduction}

There are several definitions for spices that may to some extent overlap with herbs [1-3]. Unlike herbs, which are defined as plants with non-woody tissues, spices are considered a culinary term rather than a botanical category [2]. This study is guided by the simple definition that spices are all parts of a plant that are used to improve meals in their colour, flavour, or even texture. These parts can be leaves, seeds, roots, fruits, bark, buds, or stalks [3].

The importance of spice may vary through countries worldwide [2]. Although generally thought to represent only a small portion of the human diet, they cannot be neglected as they may contribute to the overall intake of mycotoxins from all foodstuffs [4]. Spices are a widespread commodity [2] as they are exported worldwide, mainly from developing countries where they are mostly grown. Approximately 15.9 million tonnes of spices (excluding garlic and onion together exceeding 100 million tonnes) were produced in 2019 [5]. Asian countries were the largest producers of spices (share of production 75.7\%; 12.1 million tonnes), followed by African (19.9\%; 3.2 million tonnes), American (3.8\%; 0.6 million tonnes), European $(0.5 \% ; 0.08$ million tonnes), and Oceanian $(0.1 \% ; 0.012$ million tonnes) producing countries in 2019.

Unfortunately, spices are susceptible to fungal infestation and mycotoxin contamination. The local subtropical/tropical climate conditions in most spice-producing countries such as high temperatures in combination with heavy rainfalls pose a suitable environment for mould infestation and thus mycotoxin production in spices. Moreover, following 
good agricultural, hygienic, and manufacturing practices is particularly difficult in these countries, which is also likely to contribute to the deterioration of spices by moulds and mycotoxins [6-9]. Aspergillus carbonarius, A. flavus, A. ochraceus, A. parasiticus, A. tamarii, A. versicolor, Penicillium citrinum, P. verrucosum, and Fusarium verticillioides are considered the most common moulds in spices. However, Alternaria alternata, Rhizopus oryzae, and $R$. nigricans have also been found in some spices such as cumin and coriander [4]. Ochratoxin A (OTA), along with aflatoxins B1, B2, G1, and G2, citrinin, fumonisins B1 and B2, trichothecenes such as deoxynivalenol, nivalenol, T-2 toxin, and HT-2 toxin, zearalenone, altenuene, alternariol, tenuazonic acid, and sterigmatocystin, has been confirmed in spices by many studies [4].

This study focused on OTA (PubChem CID: 442530) [10], which is considered the second most important mycotoxin from the public health point of view [11]. Moreover, it is infamous mainly for its nephrotoxic and less hepatotoxic effects, however, teratogenic, genotoxic, immunotoxic, and neurotoxic effects have also been reported [12]. The International Agency for Research on Cancer classifies OTA into group 2B, which is a possible carcinogen for humans [13,14].

A recent study [4] describing the situation of spice mycotoxin and mould contamination revealed that besides the well-known and most studied spices such as chilli and black pepper, many other types of spices also deserve attention and need to be monitored for various mycotoxins. Table 1 shows a summary of the results of recent studies on the determination of OTA in several types of spices [15-46].

Table 1. Overview of studies dealing with the contamination of spices with OTA from a global perspective.

\begin{tabular}{|c|c|c|c|c|c|c|c|}
\hline Country & Spices & $n+/ n$ & $n+\%$ & $\begin{array}{l}\text { Mean } \\
\left(\mathrm{ng} \mathrm{g}^{-1}\right)\end{array}$ & $\begin{array}{l}\text { Range Min-Max } \\
\left(n g g^{-1}\right)\end{array}$ & $\begin{array}{l}\text { LOQ } \\
\left(\operatorname{ng~g~}^{-1}\right)\end{array}$ & References \\
\hline \multicolumn{8}{|l|}{ Africa } \\
\hline \multirow[t]{3}{*}{ Cameroon } & Black pepper & $2 / 20$ & 10 & 1.53 & $1.15-1.91$ & 1.00 & [15] \\
\hline & Cloves & $0 / 40$ & 0 & - & - & 1.00 & \\
\hline & White pepper & $8 / 20$ & 40 & 3.30 & $1.81-4.89$ & 1.00 & \\
\hline \multirow[t]{7}{*}{ Ivory Coast } & Black pepper & $0 / 30$ & 0 & - & - & 0.20 & [16] \\
\hline & Chilli & $25 / 30$ & 83 & $68.97^{\uparrow}$ & $0.04-907.57$ & 0.20 & \\
\hline & Ginger & $15 / 30$ & 50 & 0.22 & $0.04-0.56$ & 0.20 & \\
\hline & Black pepper & $7 / 12$ & 58 & 4.56 & $0.27-13.95$ & 0.16 & [17] \\
\hline & Chilli & $4 / 12$ & 33 & 1.50 & $0.23-4.45$ & 0.16 & \\
\hline & Dawadawa & $2 / 12$ & 17 & 1.40 & $1.26-1.55$ & 0.16 & \\
\hline & Ginger & $3 / 12$ & 25 & 0.22 & $0.17-0.31$ & 0.16 & \\
\hline Nigeria & Ginger & $57 / 120$ & 48 & 3.75 & $0.17-12.02$ & 0.30 & [18] \\
\hline \multirow[t]{5}{*}{ South Africa } & Chilli & $2 / 18$ & 11 & 16.00 & $7.00-25.00$ & 4.20 & [19] \\
\hline & $\begin{array}{l}\text { Fruit chutney } \\
\text { spices }\end{array}$ & $1 / 4$ & 25 & $6.00 *$ & $6.00 *$ & 4.20 & \\
\hline & Onion & $0 / 8$ & 0 & - & - & 4.20 & \\
\hline & Paprika & $1 / 7$ & 14 & 11.00 * & $11.00 *$ & 4.20 & \\
\hline & Vegetable spice & $0 / 1$ & 0 & - & - & 4.20 & \\
\hline \multicolumn{8}{|l|}{ America } \\
\hline \multirow[t]{8}{*}{ Brazil } & Black pepper & $0 / 15$ & 0 & - & - & $\mathrm{N} / \mathrm{S}$ & [20] \\
\hline & Chilli & $0 / 15$ & 0 & - & - & $\mathrm{N} / \mathrm{S}$ & \\
\hline & Cinnamon & $0 / 13$ & 0 & - & - & $\mathrm{N} / \mathrm{S}$ & \\
\hline & Cloves & $0 / 12$ & 0 & - & - & $\mathrm{N} / \mathrm{S}$ & \\
\hline & Fennel & $0 / 15$ & 0 & - & - & $\mathrm{N} / \mathrm{S}$ & \\
\hline & Oregano & $0 / 12$ & 0 & - & - & $\mathrm{N} / \mathrm{S}$ & \\
\hline & Rosemary & $0 / 15$ & 0 & - & - & $\mathrm{N} / \mathrm{S}$ & \\
\hline & White pepper & $0 / 15$ & 0 & - & - & $\mathrm{N} / \mathrm{S}$ & \\
\hline
\end{tabular}


Table 1. Cont.

\begin{tabular}{|c|c|c|c|c|c|c|c|}
\hline Country & Spices & $n+/ n$ & $n+\%$ & $\begin{array}{l}\text { Mean } \\
\left(n g g^{-1}\right)\end{array}$ & $\begin{array}{l}\text { Range Min-Max } \\
\left(\mathrm{ng} \mathrm{g}^{-1}\right)\end{array}$ & $\begin{array}{l}\text { LOQ } \\
\left(\operatorname{ng~g~}^{-1}\right)\end{array}$ & References \\
\hline \multicolumn{8}{|l|}{ Asia } \\
\hline \multirow[t]{9}{*}{ China } & Aniseed & $5 / 80$ & 6 & 0.73 & $\mathrm{~N} / \mathrm{S}$ & 0.50 & {$[21]$} \\
\hline & Chilli & $15 / 80$ & 19 & 6.77 & $\mathrm{~N} / \mathrm{S}$ & 0.50 & \\
\hline & Cinnamon & $4 / 80$ & 5 & 1.10 & $\mathrm{~N} / \mathrm{S}$ & 0.50 & \\
\hline & Cumin & $5 / 29$ & 17 & 1.46 & $\mathrm{~N} / \mathrm{S}$ & 0.50 & \\
\hline & Curry powder & $5 / 11$ & 46 & 2.44 & $\mathrm{~N} / \mathrm{S}$ & 0.50 & \\
\hline & Fennel & $0 / 40$ & 0 & - & - & 0.50 & \\
\hline & Pepper & $0 / 80$ & 0 & - & - & 0.50 & \\
\hline & Prickly ash & $8 / 80$ & 10 & 3.17 & $\mathrm{~N} / \mathrm{S}$ & 0.50 & \\
\hline & Liquorice & $2 / 31$ & 6 & 2.00 & $0.06-3.93$ & & [22] \\
\hline \multirow[t]{14}{*}{ India } & Chilli & $40 / 55$ & 73 & $97.10^{\uparrow}$ & $\mathrm{N} / \mathrm{S}$ & $\mathrm{N} / \mathrm{S}$ & [23] \\
\hline & Black pepper & $33 / 42$ & 79 & $154.10^{\uparrow}$ & $\mathrm{N} / \mathrm{S}$ & $\mathrm{N} / \mathrm{S}$ & \\
\hline & Caraway & $12 / 25$ & 48 & $63.20^{\nearrow}$ & $\mathrm{N} / \mathrm{S}$ & $\mathrm{N} / \mathrm{S}$ & \\
\hline & Coriander & $9 / 30$ & 30 & $47.60^{\nearrow}$ & $\mathrm{N} / \mathrm{S}$ & $\mathrm{N} / \mathrm{S}$ & \\
\hline & Cumin & $0 / 28$ & 0 & - & - & $\mathrm{N} / \mathrm{S}$ & \\
\hline & Fennel & $14 / 25$ & 56 & $98.10^{\nearrow}$ & $\mathrm{N} / \mathrm{S}$ & $\mathrm{N} / \mathrm{S}$ & \\
\hline & Fenugreek & $18 / 35$ & 51 & $83.20^{\nearrow}$ & $\mathrm{N} / \mathrm{S}$ & $\mathrm{N} / \mathrm{S}$ & \\
\hline & Ginger & $20 / 36$ & 56 & $82.80^{\uparrow}$ & $\mathrm{N} / \mathrm{S}$ & $\mathrm{N} / \mathrm{S}$ & \\
\hline & Turmeric & $20 / 35$ & 57 & $125.90^{\uparrow}$ & $\mathrm{N} / \mathrm{S}$ & $\mathrm{N} / \mathrm{S}$ & \\
\hline & Black pepper & $31 / 55$ & 56 & 155.00 & $\mathrm{~N} / \mathrm{S}$ & $\mathrm{N} / \mathrm{S}$ & [24] \\
\hline & Cardamom & $11 / 32$ & 34 & 68.00 & $\mathrm{~N} / \mathrm{S}$ & $\mathrm{N} / \mathrm{S}$ & \\
\hline & Fennel & $8 / 35$ & 23 & 10.00 & $\mathrm{~N} / \mathrm{S}$ & $\mathrm{N} / \mathrm{S}$ & \\
\hline & Mace & $18 / 30$ & 60 & 128.00 & $\mathrm{~N} / \mathrm{S}$ & $\mathrm{N} / \mathrm{S}$ & \\
\hline & Turmeric & $21 / 42$ & 50 & 162.00 & $\mathrm{~N} / \mathrm{S}$ & $\mathrm{N} / \mathrm{S}$ & \\
\hline Indonesia & Chilli & $3 / 6$ & 50 & $44.87^{\uparrow}$ & $23.70-84.60$ & 1.77 & [25] \\
\hline \multirow[t]{8}{*}{ Iran } & Black pepper & $10 / 23$ & 43 & 3.31 & $0.70-7.64$ & 0.06 & [26] \\
\hline & Cinnamon & $8 / 23$ & 35 & 5.46 & $0.45-16.10$ & 0.06 & \\
\hline & Chilli & $4 / 23$ & 17 & 5.66 & $0.56-18.64$ & 0.06 & \\
\hline & Turmeric & $7 / 23$ & 30 & 2.77 & $0.60-8.49$ & 0.06 & \\
\hline & Black pepper & $20 / 20$ & 100 & 49.29 & $15.91-197.64$ & 1.23 & \\
\hline & Cinnamon & $2 / 20$ & 10 & 18.5 & $0.70-139.44$ & 1.23 & \\
\hline & Chilli & $0 / 20$ & 0 & - & - & 1.23 & {$[27]$} \\
\hline & Turmeric & $0 / 20$ & 0 & - & - & 1.23 & \\
\hline Korea & Chilli & $6 / 56$ & 11 & 2.38 & $4.51^{\mathrm{M}}$ & 0.31 & [28] \\
\hline \multirow[t]{19}{*}{ Lebanon } & Allspice & $0 / 3$ & 0 & - & - & 1.50 & [29] \\
\hline & Anise & $1 / 3$ & 33 & $2.60 *$ & $2.60 *$ & 1.50 & \\
\hline & Basil & $0 / 2$ & 0 & - & - & 1.50 & \\
\hline & Bay leaf & $0 / 2$ & 0 & - & - & 1.50 & \\
\hline & Black pepper & $1 / 4$ & 25 & $2.30 *$ & $2.30 *$ & 1.50 & \\
\hline & Caraway & $0 / 2$ & 0 & - & - & 1.50 & \\
\hline & Cardamom & $0 / 4$ & 0 & - & - & 1.50 & \\
\hline & Chilli & $2 / 7$ & 29 & 7.70 & $\mathrm{~N} / \mathrm{S}$ & 1.50 & \\
\hline & Cinnamon & $0 / 3$ & 0 & - & - & 1.50 & \\
\hline & Cloves & $0 / 2$ & 0 & - & - & 1.50 & \\
\hline & Coriander & $0 / 2$ & 0 & - & - & 1.50 & \\
\hline & Cumin & $1 / 5$ & 20 & $3.50 *$ & $3.50 *$ & 1.50 & \\
\hline & Fennel & $0 / 2$ & 0 & - & - & 1.50 & \\
\hline & Fenugreek & $0 / 4$ & 0 & - & - & 1.50 & \\
\hline & Garlic & $1 / 2$ & 50 & $5.10 *$ & $5.10 *$ & 1.50 & \\
\hline & Ginger & $0 / 3$ & 0 & - & - & 1.50 & \\
\hline & Marjoram & $1 / 2$ & 50 & $0.75 *$ & $0.75^{*}$ & 1.50 & \\
\hline & Mint & $0 / 3$ & 0 & - & - & 1.50 & \\
\hline & Nutmeg & $1 / 2$ & 50 & $33.90 * \uparrow$ & $33.90 *$ & 1.50 & \\
\hline
\end{tabular}


Table 1. Cont.

\begin{tabular}{|c|c|c|c|c|c|c|c|}
\hline Country & Spices & $n+/ n$ & $n+\%$ & $\begin{array}{l}\text { Mean } \\
\left(\operatorname{ng~g~}^{-1}\right)\end{array}$ & $\begin{array}{l}\text { Range Min-Max } \\
\left(\mathrm{ng} \mathrm{g}^{-1}\right)\end{array}$ & 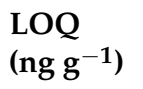 & References \\
\hline \multirow[t]{29}{*}{ Lebanon } & Onion & $0 / 4$ & 0 & - & - & 1.50 & \\
\hline & Oregano & $0 / 3$ & 0 & - & - & 1.50 & \\
\hline & Paprika & $2 / 3$ & 67 & 11.40 & $\mathrm{~N} / \mathrm{S}$ & 1.50 & \\
\hline & Parsley & $0 / 1$ & 0 & - & - & 1.50 & \\
\hline & Rosemary & $1 / 2$ & 50 & $0.75^{*}$ & $0.75^{*}$ & 1.50 & \\
\hline & Saffron & $0 / 1$ & 0 & - & - & 1.50 & \\
\hline & Sage & $1 / 3$ & 33 & $4.20 *$ & $4.20 *$ & 1.50 & \\
\hline & Sumac & $0 / 2$ & 0 & - & - & 1.50 & \\
\hline & Thyme & $0 / 3$ & 0 & - & - & 1.50 & \\
\hline & Turmeric & $1 / 2$ & 50 & $2.40 *$ & $2.40^{*}$ & 1.50 & \\
\hline & White pepper & $0 / 2$ & 0 & - & - & 1.50 & \\
\hline & Allspice & $\mathrm{N} / \mathrm{S}$ & ND & - & - & 1.50 & [30] \\
\hline & Anise & $\mathrm{N} / \mathrm{S}$ & $\mathrm{D}$ & 2.6 & $\mathrm{~N} / \mathrm{S}$ & 1.50 & \\
\hline & Black pepper & $\mathrm{N} / \mathrm{S}$ & $\mathrm{D}$ & 2.30 & $\mathrm{~N} / \mathrm{S}$ & 1.50 & \\
\hline & Cardamom & $\mathrm{N} / \mathrm{S}$ & ND & - & - & 1.50 & \\
\hline & Caraway & $\mathrm{N} / \mathrm{S}$ & ND & - & - & 1.50 & \\
\hline & Cinnamon & $\mathrm{N} / \mathrm{S}$ & ND & - & - & 1.50 & \\
\hline & Cloves & $\mathrm{N} / \mathrm{S}$ & ND & - & - & 1.50 & \\
\hline & Coriander & $\mathrm{N} / \mathrm{S}$ & ND & - & - & 1.50 & \\
\hline & Cumin & $\mathrm{N} / \mathrm{S}$ & $\mathrm{D}$ & 3.50 & $\mathrm{~N} / \mathrm{S}$ & 1.50 & \\
\hline & Fennel & $\mathrm{N} / \mathrm{S}$ & ND & - & - & 1.50 & \\
\hline & Garlic powder & $\mathrm{N} / \mathrm{S}$ & ND & - & - & 1.50 & \\
\hline & Ginger & $\mathrm{N} / \mathrm{S}$ & ND & - & - & 1.50 & \\
\hline & Nutmeg & $\mathrm{N} / \mathrm{S}$ & $\mathrm{D}$ & $34.00 \uparrow$ & $\mathrm{N} / \mathrm{S}$ & 1.50 & \\
\hline & Onion powder & $\mathrm{N} / \mathrm{S}$ & ND & - & - & 1.50 & \\
\hline & Paprika & $\mathrm{N} / \mathrm{S}$ & $\mathrm{D}$ & 11.40 & $\mathrm{~N} / \mathrm{S}$ & 1.50 & \\
\hline & Red chilli & $\mathrm{N} / \mathrm{S}$ & $\mathrm{D}$ & 7.70 & $\mathrm{~N} / \mathrm{S}$ & 1.50 & \\
\hline & Turmeric & $\mathrm{N} / \mathrm{S}$ & $\mathrm{D}$ & 2.40 & $\mathrm{~N} / \mathrm{S}$ & 1.50 & \\
\hline & White pepper & $\mathrm{N} / \mathrm{S}$ & ND & - & - & 1.50 & \\
\hline \multirow[t]{10}{*}{ Malaysia } & Coriander & $1 / 1$ & 100 & $0.91 *$ & $0.91 *$ & 0.33 & [31] \\
\hline & Cumin & $1 / 2$ & 50 & $20.40 * \nearrow$ & 20.40 * & 0.33 & \\
\hline & Curry & $8 / 8$ & 100 & 2.36 & $0.14-9.59$ & 0.33 & \\
\hline & Chilli & $1 / 2$ & 50 & $0.62 *$ & $0.62 *$ & 0.33 & \\
\hline & Fennel & $1 / 2$ & 50 & $1.26^{*}$ & $1.26^{*}$ & 0.33 & \\
\hline & Black pepper & $0 / 1$ & 0 & - & - & 0.33 & \\
\hline & Turmeric & $2 / 2$ & 100 & 1.89 & $0.20-3.58$ & 0.33 & \\
\hline & White pepper & $0 / 1$ & 0 & - & - & 0.33 & \\
\hline & Chilli & $0 / 10$ & 0 & - & - & 0.30 & {$[32]$} \\
\hline & Chilli & $65 / 80$ & 81 & 7.15 & $0.20-101.20$ & 0.06 & [33] \\
\hline \multirow[t]{5}{*}{ Pakistan } & $\begin{array}{l}\text { Chilli crushed, } \\
\text { restaurant }\end{array}$ & $14 / 28$ & 50 & 19.80 & $48.70^{\mathrm{M}}$ & 0.18 & [34] \\
\hline & $\begin{array}{l}\text { Chilli powdered, } \\
\text { restaurant }\end{array}$ & $12 / 29$ & 41 & $22.90 \uparrow$ & $58.10^{\mathrm{M}}$ & 0.18 & \\
\hline & $\begin{array}{l}\text { Chilli crushed, } \\
\text { open market }\end{array}$ & $11 / 29$ & 38 & 16.90 & $54.30^{\mathrm{M}}$ & 0.18 & \\
\hline & $\begin{array}{l}\text { Chilli powdered, } \\
\text { open market }\end{array}$ & $13 / 34$ & 38 & $21.40^{\uparrow}$ & $64.50^{\mathrm{M}}$ & 0.18 & \\
\hline & Chilli & $99 / 242$ & 41 & $\mathrm{~N} / \mathrm{S}$ & $120.90^{\mathrm{M}}$ & 0.30 & {$[35]$} \\
\hline Saudi Arabia & Cardamom & $38 / 80$ & 48 & $60.14 \nearrow$ & $30.00-78.00$ & 3.33 & {$[36]$} \\
\hline \multirow[t]{5}{*}{ Sri Lanka } & Chilli flakes & $13 / 26$ & 50 & 4.90 & $15.00^{\mathrm{M}}$ & $\mathrm{N} / \mathrm{S}$ & {$[37]$} \\
\hline & Chilli pods & $2 / 18$ & 11 & $\mathrm{~N} / \mathrm{S}$ & $5.30^{\mathrm{M}}$ & $\mathrm{N} / \mathrm{S}$ & \\
\hline & Red chilli powder & $20 / 42$ & 48 & 16.00 & $282.00^{\mathrm{M}}$ & $\mathrm{N} / \mathrm{S}$ & \\
\hline & Black pepper & $\mathrm{N} / \mathrm{S}$ & $\mathrm{D}$ & $\mathrm{N} / \mathrm{S}$ & $79.00 \mathrm{M} \uparrow$ & $\mathrm{N} / \mathrm{S}$ & [38] \\
\hline & Chilli & $35 / 86$ & 41 & $\mathrm{~N} / \mathrm{S}$ & $282.00^{\mathrm{M}}$ & $\mathrm{N} / \mathrm{S}$ & \\
\hline
\end{tabular}


Table 1. Cont.

\begin{tabular}{|c|c|c|c|c|c|c|c|}
\hline Country & Spices & $n+/ n$ & $n+\%$ & $\begin{array}{l}\text { Mean } \\
\left(\mathrm{ng} \mathrm{g}^{-1}\right)\end{array}$ & $\begin{array}{l}\text { Range Min-Max } \\
\left(\mathrm{ng} \mathrm{g}^{-1}\right)\end{array}$ & $\begin{array}{l}\text { LOQ } \\
\left(\operatorname{ng~g~}^{-1}\right)\end{array}$ & References \\
\hline \multirow[t]{4}{*}{ Turkey } & Black pepper & $4 / 23$ & 17 & 0.34 & $3.48^{\mathrm{M}}$ & 0.19 & \multirow[t]{4}{*}{ [39] } \\
\hline & Cumin & $1 / 19$ & 5 & $0.63 *$ & $0.63 *$ & 0.19 & \\
\hline & Red chilli flakes & $18 / 24$ & 75 & 12.34 & $53.04^{\mathrm{M}}$ & 0.19 & \\
\hline & Red chilli powder & $12 / 22$ & 55 & 13.46 & $98.20^{M}$ & 0.19 & \\
\hline \multicolumn{8}{|l|}{ Europe } \\
\hline Czech & Black pepper & $11 / 12$ & 92 & 0.83 & $2.82^{\mathrm{M}}$ & 0.20 & \multirow[t]{9}{*}{ [40] } \\
\hline \multirow[t]{8}{*}{ Republic } & Caraway & $2 / 12$ & 17 & 0.19 & $0.71^{\mathrm{M}}$ & 0.20 & \\
\hline & Chilli pepper dried & $11 / 12$ & 92 & 6.70 & $32.70^{\mathrm{M}}$ & 0.20 & \\
\hline & Coriander seed & $4 / 12$ & 33 & 0.46 & $1.96^{\mathrm{M}}$ & 0.20 & \\
\hline & $\begin{array}{l}\text { Fiery paprika } \\
\text { powder }\end{array}$ & $12 / 12$ & 100 & 19.00 & $5.5-91.80$ & 0.20 & \\
\hline & Ginger root dried & $7 / 12$ & 58 & 2.04 & $12.70^{\mathrm{M}}$ & 0.20 & \\
\hline & Liquorice & $12 / 12$ & 100 & 15.80 & $3.8-36.70$ & 0.20 & \\
\hline & \multirow{2}{*}{$\begin{array}{l}\text { Nutmeg } \\
\text { Sweet paprika } \\
\text { powder }\end{array}$} & $12 / 12$ & 100 & 8.70 & $0.3-60.70$ & 0.20 & \\
\hline & & $12 / 12$ & 100 & 16.00 & $1.1-38.40$ & 0.20 & \\
\hline \multirow[t]{4}{*}{ Hungary } & \multirow{4}{*}{$\begin{array}{l}\text { Black pepper } \\
\text { Chilli } \\
\text { Red pepper, } \\
\text { ground } \\
\text { White pepper }\end{array}$} & $0 / 6$ & 0 & - & - & 0.60 & \multirow{4}{*}[41]{} \\
\hline & & $1 / 5$ & 20 & $2.1 *$ & $2.1 *$ & 0.60 & \\
\hline & & $32 / 70$ & 46 & $\mathrm{~N} / \mathrm{S}$ & $0.4-66.2$ & 0.60 & \\
\hline & & $0 / 5$ & 0 & - & - & 0.60 & \\
\hline \multirow[t]{3}{*}{ Italy } & Paprika & $17 / 31$ & 55 & $39.64^{\uparrow}$ & $0.11-177.40$ & 0.22 & {$[42]$} \\
\hline & Chilli & $15 / 25$ & 60 & $\mathrm{~N} / \mathrm{S}$ & $2.16-16.35$ & 2.13 & \multirow{2}{*}[43]{} \\
\hline & Pepper & $4 / 30$ & 13.3 & $\mathrm{~N} / \mathrm{S}$ & $1.61-15.85$ & 2.61 & \\
\hline \multirow[t]{5}{*}{ Latvia } & Basil & $0 / 50$ & 0 & - & - & 2.40 & \multirow[t]{5}{*}{ [44] } \\
\hline & Black pepper & $0 / 50$ & 0 & - & - & 1.50 & \\
\hline & Nutmeg & $\mathrm{N} / \mathrm{S}$ & $\mathrm{D}$ & $\mathrm{N} / \mathrm{S}$ & $14.00 *$ & 1.50 & \\
\hline & Oregano & $0 / 50$ & 0 & - & - & 2.40 & \\
\hline & Thyme & $0 / 50$ & 0 & - & - & 2.40 & \\
\hline \multirow[t]{18}{*}{ Poland } & Allspice & $1 / 5$ & 20 & $0.20 *$ & $0.20 *$ & 0.30 & \multirow[t]{18}{*}{ [45] } \\
\hline & Basil & $1 / 3$ & 33 & $0.05 *$ & $0.05 *$ & 0.30 & \\
\hline & Black pepper, grain & $4 / 4$ & 100 & $23.57 \uparrow$ & $\mathrm{N} / \mathrm{S}$ & 0.30 & \\
\hline & $\begin{array}{l}\text { Black pepper, } \\
\text { ground }\end{array}$ & $4 / 5$ & 80 & 9.46 & $\mathrm{~N} / \mathrm{S}$ & 0.30 & \\
\hline & Cayenne pepper & $5 / 8$ & 63 & $45.64^{\uparrow}$ & $\mathrm{N} / \mathrm{S}$ & 0.30 & \\
\hline & Cinnamon & $3 / 4$ & 75 & 2.14 & $\mathrm{~N} / \mathrm{S}$ & 0.30 & \\
\hline & Cloves & $1 / 2$ & 50 & 0.48 * & $0.48^{*}$ & 0.30 & \\
\hline & Curry & $5 / 5$ & 100 & $19.01 \nearrow$ & $\mathrm{N} / \mathrm{S}$ & 0.30 & \\
\hline & Garlic & $2 / 3$ & 67 & 0.11 & $\mathrm{~N} / \mathrm{S}$ & 0.30 & \\
\hline & Marjoram & $4 / 5$ & 80 & 7.13 & $\mathrm{~N} / \mathrm{S}$ & 0.30 & \\
\hline & Nutmeg & $2 / 5$ & 40 & 2.73 & $\mathrm{~N} / \mathrm{S}$ & 0.30 & \\
\hline & Oregano, whole & $1 / 2$ & 50 & $9.38 *$ & $9.38 *$ & 0.30 & \\
\hline & Oregano, crushed & $2 / 4$ & 50 & $22.12^{\nearrow}$ & $\mathrm{N} / \mathrm{S}$ & 0.30 & \\
\hline & Rosemary & $1 / 2$ & 50 & $5.07 *$ & $5.07^{*}$ & 0.30 & \\
\hline & Tarragon & $1 / 1$ & 100 & $6.98 *$ & $6.98 *$ & 0.30 & \\
\hline & Thyme & $3 / 3$ & 100 & $15.59 \nearrow$ & $\mathrm{N} / \mathrm{S}$ & 0.30 & \\
\hline & Turmeric & $1 / 1$ & 100 & $11.72 *$ & $11.72 *$ & 0.30 & \\
\hline & White pepper & $6 / 7$ & 86 & $29.41 \uparrow$ & $\mathrm{N} / \mathrm{S}$ & 0.30 & \\
\hline \multirow[t]{2}{*}{ Spain } & Chilli & $35 / 35$ & 100 & $\mathrm{~N} / \mathrm{S}$ & $0.62-44.60$ & 0.10 & \multirow[t]{2}{*}{ [46] } \\
\hline & Paprika & $63 / 64$ & 98 & $\mathrm{~N} / \mathrm{S}$ & $281.00^{\mathrm{M}}$ & 0.10 & \\
\hline
\end{tabular}

Note: $n$ : number of samples; $n+:$ number of positive samples: $n+\%$ : per cent of positive samples; ${ }^{*}$ : the only measured concentration; ${ }^{\mathrm{M}}$ : the maximum concentration (the whole range is not known); -: no data; N/S: not specified; D: detected (the quantity of positive samples is not known); ND: not detected; $\uparrow:$ the average OTA concentrations in regulated spices exceeding the relevant European Union limits EC No. $1881 / 2006$ as in force [47]; $\nearrow$ : the average OTA concentrations exceeding the limit of $15 \mathrm{ng} \mathrm{g}^{-1}$, which is currently proposed for 'all spices' by the European Commission [48]. 
However, several single-kind spices have never (or not recently) been tested for OTA. Therefore, this study aims to determine OTA in a wider range of spice types to obtain an overview of the current state of the OTA contamination of spices sold on the Czech market. As far as the authors know, globally, this is the first study dealing with OTA in many kinds of spices that are based on a single plant species.

\section{Materials and Methods}

\subsection{Sample Collecting}

Fifty-four single-kind of traditional and less traditional spices (six samples of different batches per kind of spice, 324 samples in total, each in the amount of 30-100 g) were collected in the years 2019-2020. Of this number, 300 samples (92.6\%) were imported and 24 samples $(7.4 \%)$ were of Czech provenance. The characterisation of all single-kind spice samples was performed (see Table 2). All samples were stored in consumer packaging or polypropylene bags at laboratory temperature $\left(21 \pm 0.5^{\circ} \mathrm{C}\right)$ in a dry place in the dark until sample preparation before analysis. Most samples originated from Asian and European countries (see Figure 1).

Table 2. The characterisation of spice samples.

\begin{tabular}{|c|c|c|c|c|}
\hline No. & Spices & Latin Name & Form & Country of Origin \\
\hline 1 & Allspice & Pigmenta officinalis Lindl. & milled & Mexico \\
\hline 2 & Anise & Pimpinella anisum L. & whole & Egypt \\
\hline 3 & Asafoetida * & Ferula assa-foetida L. & milled & India \\
\hline 4 & Basil & Ocimum basilicum L. & scrubbed & Egypt \\
\hline 5 & Bay leaf & Laurus nobilis L. & milled & Turkey \\
\hline 6 & Black cumin * & Nigella sativa L. & whole & India \\
\hline 7 & Black pepper & Piper nigrum L. & milled & Spain \\
\hline 8 & Calamint* & Saturea hortensis L. & scrubbed & Germany \\
\hline 9 & Caraway & Carum carvi L. & milled & Czech Republic \\
\hline 10 & Cardamom & Elateria cardamomum L. & milled & Guatemala \\
\hline 11 & Cayenne pepper & Capsicum frutescens $\mathrm{L}$. & milled & Indonesia \\
\hline 12 & Celery root* & Apium graveolens L. & whole & Czech Republic \\
\hline 13 & Chervil * & Anthriscus cerefolium (L.) Hoffm. & scrubbed & Germany \\
\hline 14 & Chilli crushed with seeds & Capsicum frutescens $L$. & crushed & Thailand \\
\hline 15 & Chilli milled & Capsicum frutescens $\mathrm{L}$. & milled & India \\
\hline 16 & Chives* & Allium schoenoprasum L. & chopped & China \\
\hline 17 & Cinnamon & $\begin{array}{l}\text { Cinnamomum burmannii (Nees \& Th. Nees) } \\
\text { Nees ex Blume }\end{array}$ & milled & Indonesia \\
\hline 18 & Citronella * & Cymbopogon citratus (DC- ex Nees) Stapf & cut & Albania \\
\hline 19 & Clove & Eugenia caryophyllata L. & milled & Madagascar \\
\hline 20 & Coriander & Coriandrum satioum L. & milled & Czech Republic \\
\hline 21 & Cumin & Cuminum cyminum L. & milled & India \\
\hline 22 & Dried dill tip * & Anetum graveolens L. & chopped & Czech Republic \\
\hline 23 & Fennel & Foeniculum vulgare Mill. & whole & Egypt \\
\hline 24 & Fenugreek & Trigonella foenum-graecum L. & milled & India \\
\hline 25 & Galangal root* & Alpinia glanga (L.) Wild. & milled & China \\
\hline 26 & Garlic & Allium sativum L. & granulated & China \\
\hline 27 & Ginger & Zingiber officinale Roscoe & milled & Peru \\
\hline 28 & Green pepper* & Piper nigrum L. & milled & India \\
\hline 29 & Juniper* & Juniperus communis L. & milled & Pakistan \\
\hline 30 & Lemon peel * & Citrus limon (L.) Burm. f. & milled & Spain \\
\hline 31 & Liquorice root & Glycyrhiza glabra L. & crushed & China \\
\hline 32 & Lovage* & Levisticum officinale W.D.J. Koch & cut & Poland \\
\hline 33 & Mace & Myristica fragrans Houtt. & milled & Indonesia \\
\hline 34 & Marjoram & Majorana hortensis L. & scrubbed & Egypt \\
\hline 35 & Mint & Mentha piperita $\mathrm{L}$. & milled & Egypt \\
\hline 36 & Nutmeg & Myristica fragrans Houtt. & milled & Indonesia \\
\hline 37 & Orange peel * & Citrus aurantium L. & milled & Spain \\
\hline 38 & Oregano & Origanum vulgare L. & cut & Turkey \\
\hline
\end{tabular}


Table 2. Cont.

\begin{tabular}{|c|c|c|c|c|}
\hline No. & Spices & Latin Name & Form & Country of Origin \\
\hline 39 & Parsley & Petroselinum sativum Hoffm. & chopped & Poland \\
\hline 40 & Pink pepper * & Schinus terebinthifolius Raddi & whole & Brazil \\
\hline 41 & Rosemary & Rosmarinus officinalis L. & cut & Morocco \\
\hline 42 & Saffron & Crocus sativus L. & whole & Spain \\
\hline 43 & Sage & Salvia officinalis L. & scrubbed & Germany \\
\hline 44 & Sichuan pepper* & Zanthoxylum piperitum (L.) DC. & whole & China \\
\hline 45 & Star anise * & Illicium verum Hook. f. & milled & India \\
\hline 46 & Sumac & Rhus coriaria $\mathrm{L}$. & milled & Turkey \\
\hline 47 & Sweet paprika & Capsicum annuum L. & milled & Hungary \\
\hline 48 & Tarragon cut & Artemisia dracunculus L. & cut & Poland \\
\hline 49 & Thyme & Thymus vulgaris L. & whole & Poland \\
\hline 50 & Turmeric & Curcuma longa $\mathrm{L}$. & milled & India \\
\hline 51 & Vanilla * & Vanilla planifolia Jacks. Ex Andrews & milled & Tahiti \\
\hline 52 & White pepper & Piper nigrum $\mathrm{L}$ & milled & Vietnam \\
\hline 53 & White mustard * & Sinapis alba $\mathrm{L}$. & milled & Ukraine \\
\hline 54 & Wild garlic* & Allium usrinum L. & cut & Bulgaria \\
\hline
\end{tabular}

Notes: *: spices in which OTA has never (or not recently) been studied according to the available literature (see Table 1).

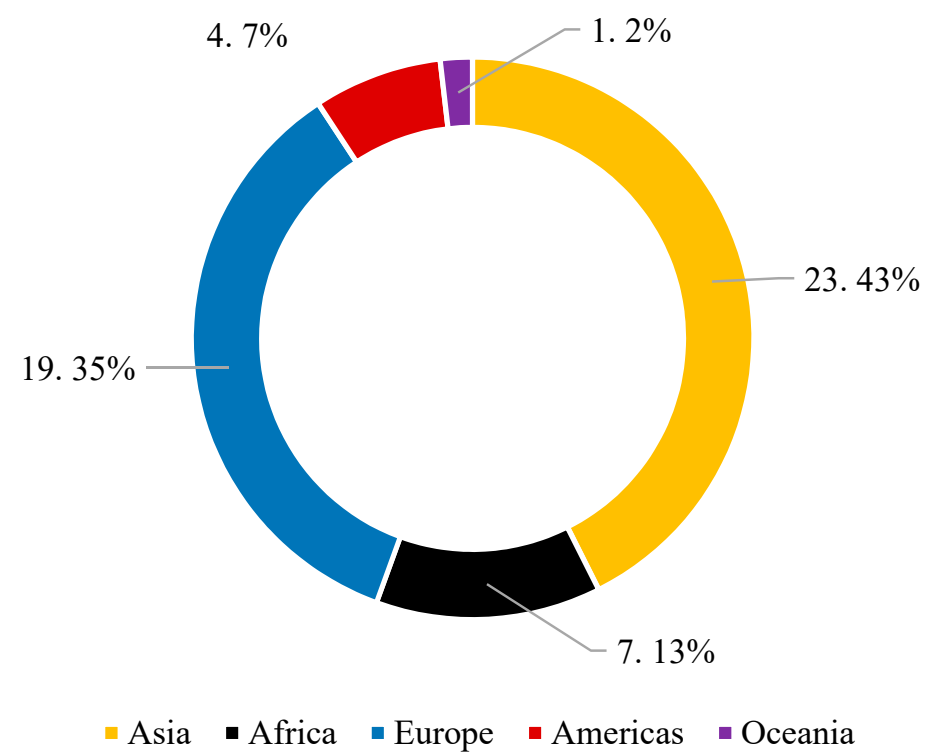

Figure 1. The origin of spice samples.

\subsection{Sample Preparation-OTA Purification by Immunoaffinity Chromatography}

All spice samples were properly homogenised using a laboratory homogenizer. The separation step was performed using a modified method according to Zimmerli and Dick [49] using immunoaffinity chromatography to increase both the selectivity and sensitivity of the method. The immunoaffinity chromatography uses immunoaffinity columns (IACs) operating specifically on the principle of antigen-antibody. The method consists of binding the antigen (OTA) by special anti-OTA antibodies anchored in the column. After the application of the washing solution, the other potentially interfering substances are removed from the column. The bound OTA is then released with acidified methanol from the antigen-antibody complex [49].

\subsection{Chemicals and Apparatus}

Methanol $\left(\mathrm{CH}_{3} \mathrm{OH}\right)$, acetonitrile $\left(\mathrm{C}_{2} \mathrm{H}_{3} \mathrm{~N}\right)$, and chloroform $\left(\mathrm{CHCl}_{3}\right)$ (all of HiPerSolv CHROMANORM gradient grade), formic acid 85\% (HCOOH) pro-analysis (p.a.), orthophosphoric acid 85\% $\left(\mathrm{H}_{3} \mathrm{PO}_{4}\right)$ (HiPerSolv CHROMANORM), glacial acetic acid $\left(\mathrm{CH}_{3} \mathrm{COOH}\right)$, di-sodium hydrogen phosphate anhydrous $\left(\mathrm{Na}_{2} \mathrm{HPO}_{4}\right)$, sodium hydrogen 
carbonate $\left(\mathrm{NaHCO}_{3}\right)$, sodium chloride $(\mathrm{NaCl})$, and sodium hydroxide $(\mathrm{NaOH})$ (all of AnalaR NORMAPUR) were purchased from VWR (Stříbrná Skalice, Czech Republic). All chemicals were stored at laboratory temperature $21 \pm 0.5^{\circ} \mathrm{C}$. Analytical standard of OTA (Petromyces albertensis, $\geq 98 \%$, HPLC) was purchased from VWR (Stříbrná Skalice, Czech Republic) and produced by Sigma-Aldrich spol. s r.o. (Prague, Czech Republic). The analytical standard was stored in a laboratory freezer at $-20^{\circ} \mathrm{C}$. Immunoaffinity columns (IACs) OCHRAPREP ${ }^{\circledR}$ were purchased from Jemo Trading spol. s r.o., Profood (Bratislava, Slovakia) and produced by R-Biopharm (Darmstadt, Germany). Nylon syringe filters $(13 \mathrm{~mm}, 0.22 \mu \mathrm{m})$ produced by Labstore (Inverness, Highland, UK) and were purchased from HPST s.r.o. (Prague, Czech Republic).

All solutions were prepared in ultrapure water using a Milli-Q system (Millipore, Milford, MA, USA) (hereinafter referred to as 'water'). The resistivity of ultrapure water was $>18.2 \mathrm{M} \Omega . \mathrm{cm}$ at $25^{\circ} \mathrm{C}$

A IKA A 10 basic homogeniser manufactured by IKA-WERKE GMBH \& CO. KG (Staufen, Germany) was purchased from Fisher Scientific, spol. s r.o. (Pardubice, Czech Republic); an analytical balance KERN EW1500-2 manufactured by KERN \& SOHN GmbH (Balingen, Germany) was purchased from Fisher Scientific, spol. s r.o. (Pardubice, Czech Republic); a Reax Multi shaker manufactured by Heidolph Instruments GmbH \& Co. KG (Schwabach, Germany) was purchased from Fisher Scientific, spol. s r.o. (Pardubice, Czech Republic); and a laboratory centrifuge MPW 351e manufactured by MPW MED. Instruments (Warsaw, Poland) was purchased from Unimed Praha, spol. s r.o. (Prague, Czech Republic).

HPLC-FLD, Agilent 1260 Infinity II coupled to 1260 Infinity II Fluorescence Detector manufactured by Agilent (Santa Clara, CA, USA) was purchased from HPST s.r.o. (Prague, Czech Republic).

\subsection{Solution Preparation}

\subsubsection{3\% Solution of Sodium Hydrogen Carbonate $\left(\mathrm{NaHCO}_{3}\right)$}

A total of $30 \mathrm{~g}$ of $\mathrm{NaHCO}_{3}$ was quantitatively transferred to a $1000 \mathrm{~mL}$ volumetric flask (hereinafter referred to as 'flask') and dissolved in a small amount of water. After dissolving the batch, the flask was made up with water.

\subsubsection{Phosphate Saline Buffer Containing $15 \%$ Methanol (PBS-15\% Methanol)}

PBS consists of two solutions: solution $\mathrm{A}\left(0.02 \mathrm{~mol} \mathrm{~L}^{-1} \mathrm{Na}_{2} \mathrm{HPO}_{4}\right.$ at $\mathrm{pH}$ 7.4) and solution B $\left(0.29 \mathrm{~mol} \mathrm{~L}^{-1} \mathrm{NaCl}\right)$. Solution A: A total of $1.42 \mathrm{~g}$ of $\mathrm{NaHPO}_{4}$ was quantitatively transferred to a $500 \mathrm{~mL}$ flask and dissolved in a small amount of water. After dissolving the batch, the flask was made up with water. The $\mathrm{pH}$ at 7.4 was adjusted with $85 \% \mathrm{H}_{3} \mathrm{PO}_{4}$. Solution B: A total of $8.47 \mathrm{~g}$ of $\mathrm{NaCl}$ was quantitatively transferred to a $500 \mathrm{~mL}$ flask and dissolved in a small amount of water. After dissolving the batch, the flask was made up with water. PBS was obtained by mixing both prepared solutions A and B in a ratio of 1:1. PBS is stable for one year. PBS-15\% methanol was obtained by mixing $850 \mathrm{~mL}$ of PBS and $150 \mathrm{~mL}$ of methanol.

2.4.3. 3\% Buffer Solution of Ortho-Phosphoric Acid $\left(\mathrm{H}_{3} \mathrm{PO}_{4}\right)$ and Sodium Chloride $(\mathrm{NaCl})$ at $\mathrm{pH} 1.6$

A total of $116.9 \mathrm{~g}$ of $\mathrm{NaCl}$ was quantitatively transferred to a $1000 \mathrm{~mL}$ flask and dissolved in a small amount of water. After dissolving the batch, a total of $33.7 \mathrm{~mL}$ of $\mathrm{H}_{3} \mathrm{PO}_{4}$ was pipetted into the flask. The flask was made up with water. The $\mathrm{pH}$ at 1.6 was adjusted with $\mathrm{NaOH}$. The solution is stable for six months.

\subsubsection{Elution Solution of Methanol $\left(\mathrm{CH}_{3} \mathrm{OH}\right)$ Acidified by Glacial Acetic Acid $\left(\mathrm{CH}_{3} \mathrm{COOH}\right)$}

A total of $2 \mathrm{~mL}$ of $\mathrm{CH}_{3} \mathrm{COOH}$ was pipetted into a $100 \mathrm{~mL}$ flask. The flask was made up with $\mathrm{CH}_{3} \mathrm{OH}$. 
All of these solutions were kept at $5 \pm 0.5^{\circ} \mathrm{C}$. Before direct use, they were tempered at a laboratory temperature of $21 \pm 0.5^{\circ} \mathrm{C}$.

\subsubsection{OTA Working Standard Solution at a Concentration of $40 \mu \mathrm{g} \mathrm{L}{ }^{-1}(25 \mathrm{~mL})$}

A total of $100 \mu \mathrm{L}$ of OTA stock solution at concentration of $1000 \mu \mathrm{g} \mathrm{L}^{-1}$ was pipetted into a $25 \mathrm{~mL}$ flask. The flask was made up with $\mathrm{CH}_{3} \mathrm{OH}$.

Stock and working standard solutions were kept at $-20 \pm 0.5^{\circ} \mathrm{C}$.

\subsubsection{Calibration OTA Standards}

A total of six calibration OTA standards $\left(0.10,0.25,0.50,1.00,2.00\right.$, and $\left.4.0 \mathrm{ng} \mathrm{mL}^{-1}\right)$ were prepared with a linear response on each day of the measurement from the working solution $\left(40 \mu \mathrm{g} \mathrm{L}^{-1}\right)$ by its dilution in the mobile phase (MP) in a ratio reaching the target concentration. The determination coefficient was 0.9999. A blank sample consisting of the mobile phase was also prepared fresh daily.

\subsubsection{Mobile Phase (MP)}

The MP consisted of two solutions: solution A (acetonitrile:acetic acid, 99:1) and solvent B (water:acetic acid, 99:1). Solvents were used in ratio 40:60; A:B.

\subsection{Workflow}

\subsubsection{OTA Extraction}

A total of $2 \mathrm{~g}$ of the sample was weighed into a polypropylene centrifuge tube (hereinafter referred to as the tube), $10 \mathrm{~mL}$ of buffer was added and left to shake using Vortex (1 min). The extraction step with $4 \times 5 \mathrm{~mL}$ of chloroform was performed using Vortex ( $3 \mathrm{~min}$ ) and a centrifuge $\left(15 \mathrm{~min} ; 3305 \times \mathrm{g}\right.$; at laboratory temperature $\left.21 \pm 0.5^{\circ} \mathrm{C}\right)$. The lower chloroform phase was collected into a glass vial and left to evaporate under nitrogen at $45^{\circ} \mathrm{C}$ to dryness. The residue was dissolved in $5 \mathrm{~mL}$ of chloroform using Vortex (5 min). The dissolved residuum was transferred to a new tube. Extraction with $2 \times 5 \mathrm{~mL}$ of $3 \%$ solution of sodium bicarbonate was performed using Vortex ( $3 \mathrm{~min}$ ) and a centrifuge ( $5 \mathrm{~min}$; $2000 \times g$, at laboratory temperature $21 \pm 0.5^{\circ} \mathrm{C}$ ) to achieve a compact thin layer between two phases. The upper aqueous bicarbonate phase was collected into a new tube in which $1 \mathrm{~mL}$ of chloroform and $0.5 \mathrm{~mL}$ of $85 \%$ formic acid had been prepared. The re-extraction of aqueous bicarbonate with $2 \times 2 \mathrm{~mL}$ of chloroform was performed using the Vortex ( $3 \mathrm{~min}$ ) and centrifuge ( $5 \mathrm{~min} ; 2000 \times \mathrm{g}$, at laboratory temperature $21 \pm 0.5^{\circ} \mathrm{C}$ ) to achieve a compact thin layer between two phases. The lower chloroform phase at the bottom of the tube was collected into a glass vial and left to evaporate to dryness under a nitrogen stream at $45^{\circ} \mathrm{C}$.

\subsubsection{OTA Separation}

The residue was dissolved in $20 \mathrm{~mL}$ of PBS-methanol 15\% using Vortex (5 min). A laboratory ultrasonic bath was used $(10 \mathrm{~min})$ to enhance the dissolution of the residue.

The IACs were brought to the laboratory temperature (at $21 \pm 0.5^{\circ} \mathrm{C}$ for approximately $\frac{1}{2}-1 \mathrm{~h}$ ) and the buffer was released. A total of $20 \mathrm{~mL}$ of PBS-methanol $15 \%$ was transferred to the reservoir above the IAC and left to pass through IAC (at one drop per second; $2 \mathrm{~mL} \mathrm{~min}^{-1}$ ). The IACs were purified with $20 \mathrm{~mL}$ of water (at one drop per s) followed by brief air sieving (1-2 s). The elution of potential OTA was performed with $1.5 \mathrm{~mL}$ of methanol:acetic acid (98:2) into a small glass vial (at one drop per second) and followed by strong air sieving $(30 \mathrm{~s})$. The $1.5 \mathrm{~mL}$ eluate was evaporated under a nitrogen stream at $45^{\circ} \mathrm{C}$ to dryness and kept in the laboratory fridge at $4{ }^{\circ} \mathrm{C}$ until analysis with HPLC-FLD. Before analysis, samples were dissolved in $0.5 \mathrm{~mL}$ of MP using an ultrasonic bath (5 min; $37 \mathrm{kHz}$; at laboratory temperature $21 \pm 0.5^{\circ} \mathrm{C}$ ) and passed through a nylon syringe filter $(13 \mathrm{~mm}, 0.22 \mu \mathrm{m})$ into a vial for HPLC. 


\subsubsection{Analysis of Ochratoxin A in Spices by HPLC-FLD}

HPLC-FLD was employed for the determination of OTA. The column (Kinetex C18, $2.6 \mu \mathrm{m}, 100 \AA, 50 \times 21 \mathrm{~mm}$ ) coupled with a security GuardTM column (Phenomenex C18, $4 \times 2.0 \mathrm{~mm}$ ) was purchased from Chromservis s.r.o. (Prague, Czech Republic) and were used and kept at $30^{\circ} \mathrm{C}$. The MP was set at a flow rate of $0.2 \mathrm{~mL} \mathrm{~min}^{-1}$. The injection volume was $8.0 \mu \mathrm{L}$. Fluorescence detection was performed at an excitation wavelength of $333 \mathrm{~nm}$ and an emission wavelength of $465 \mathrm{~nm}$, PMT gain 18, attenuation $100 \mathrm{LU}$. Chromatography software Agilent OpenLab software was used to collect the chromatographic data. The method was validated. The limit of detection (LOD) was $0.03 \mathrm{ng} \mathrm{g}^{-1}$ and the limit of quantification (LOQ) was $0.1 \mathrm{ng} \mathrm{g}^{-1}$. The recovery of the method was verified using samples spiked with OTA. No reference material for the determination of OTA in spices was available during the period of this research. Therefore, the recovery was performed via spiked spice samples at OTA concentration levels of 0.5 and $2.0 \mathrm{ng} \mathrm{g}^{-1}$. OTA levels of $0.5 \mathrm{ng} \mathrm{g}^{-1}$ and $2.0 \mathrm{ng} \mathrm{g}^{-1}$ were added to the matrix before the extraction step, both concentrations in triplicate. The same concentrations were added after the separation step on immunoaffinity columns to the eluate, both concentrations in triplicate again. A total of 12 spiked samples were analysed for OTA. The recovery was determined for both concentration levels based on matrix effect-the ratio of the mean concentrations of samples with spiked matrix and samples with spiked eluate. The mean recovery was $74.2 \%$, which fulfils the requirements of Regulation (EC) No. 401/2006 [50]. The repeatability standard deviation (RSD) was $0.76 \%$. The mean measurement uncertainty was $4.03 \%$ including all kind of spices. OTA retention time was $5.4 \mathrm{~min}$. The calibration curve consisted of six levels of concentrations $\left(0.10,0.25,0.50,1.00,2.00\right.$, and $\left.4.00 \mathrm{ng} \mathrm{mL}^{-1}\right)$. All samples with a concentration outside the calibration curve were diluted or concentrated to reach value within the calibration curve. The chromatographs of OTA standard solution $\left(4.00 \mathrm{ng} \mathrm{mL}^{-1}\right)$ and one of the samples (33-mace) are shown in Figure 2.

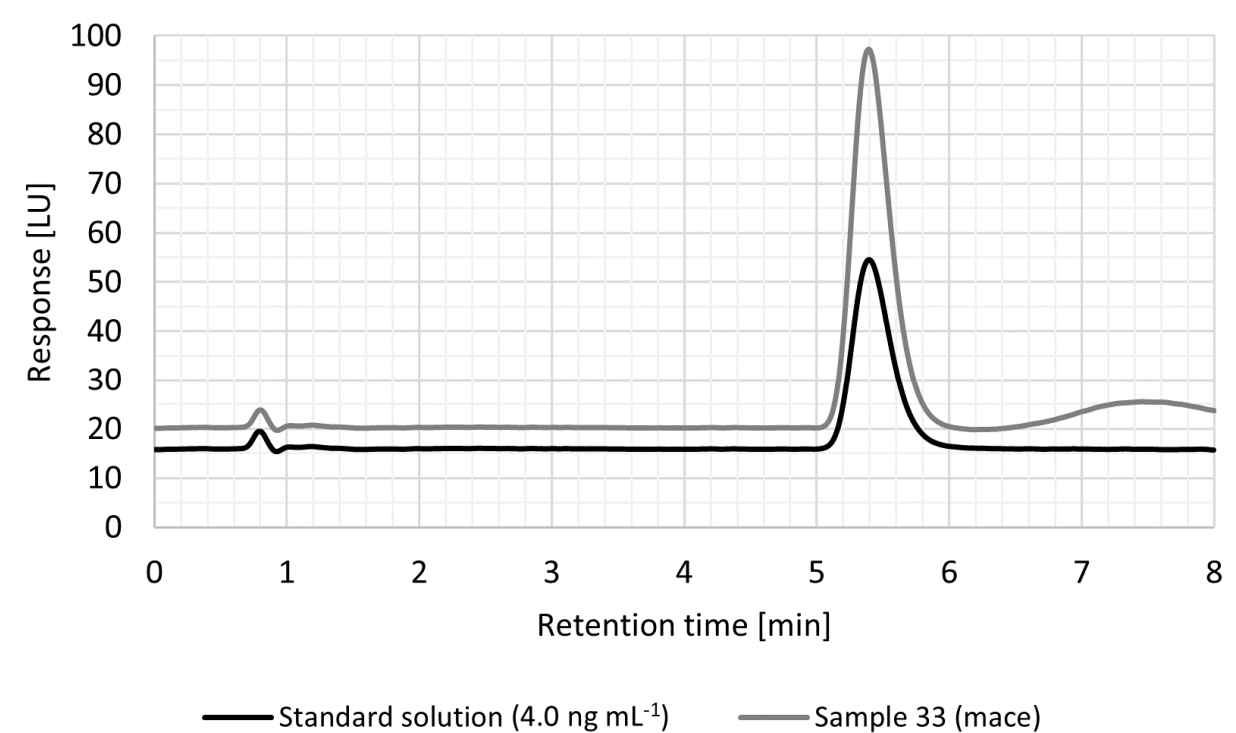

Figure 2. HPLC-FLD chromatogram showing peaks of OTA in spice sample 33 (mace) and standard solution $\left(4.0 \mathrm{ng} \mathrm{mL}^{-1}\right)$ at a retention time of $5.4 \mathrm{~min}$.

\section{Results}

A total of 101 (31\%) spice samples of 19 spice kinds were positive (exceeding LOQ of $0.1 \mathrm{ng} \mathrm{g}^{-1}$ ) for OTA (see Table 3). The concentrations of positive samples were in the range of $0.11 \mathrm{ng} \mathrm{g}^{-1}$ (for pink pepper) to $38-46 \mathrm{ng} \mathrm{g}^{-1}$ (for turmeric). 
Table 3. The concentrations of OTA in a total of 20 positive single-kind spices available on the Czech market.

\begin{tabular}{|c|c|c|c|c|c|c|}
\hline No. & Kind of Spice & Incidence $n+/ n$ & $\begin{array}{l}\text { Mean } \pm \text { SD } \\
\left(\mathrm{ng} \mathrm{g}^{-1}\right)\end{array}$ & $\begin{array}{l}\text { Median } \\
\left(n g g^{-1}\right)\end{array}$ & $\begin{array}{l}\text { 95th Perc. } \\
\left(\mathrm{ng} \mathrm{g}^{-1}\right)\end{array}$ & $\begin{array}{c}\text { Range Min-Ma } \\
\text { X }\left(\mathrm{ng} \mathrm{g}^{-1}\right)\end{array}$ \\
\hline 50 & Turmeric & $6 / 6$ & $19.82 \pm 11.93$ & 17.04 & 36.01 & $5.13-38.46$ \\
\hline 31 & Liquorice root & $6 / 6$ & $11.94 \pm 3.27$ & 12.10 & 16.18 & $7.57-17.42$ \\
\hline 15 & Chilli milled & $6 / 6$ & $7.50 \pm 1.34$ & 7.78 & 8.96 & $5.28-9.27$ \\
\hline 33 & Mace & $6 / 6$ & $5.27 \pm 0.83$ & 5.25 & 6.22 & $3.94-6.33$ \\
\hline 27 & Ginger & $6 / 6$ & $3.40 \pm 0.48$ & 3.46 & 3.91 & $2.18-3.93$ \\
\hline 11 & Cayenne pepper & $6 / 6$ & $2.59 \pm 0.61$ & 2.71 & 3.21 & $1.67-3.27$ \\
\hline 47 & Sweet paprika & $6 / 6$ & $2.26 \pm 0.60$ & 1.99 & 3.06 & $1.73-3.12$ \\
\hline 14 & Chilli crushed with seeds & $6 / 6$ & $1.43 \pm 0.48$ & 1.41 & 1.98 & $0.82-2.03$ \\
\hline 51 & Vanilla & $6 / 6$ & $1.42 \pm 0.33$ & 1.49 & 1.72 & $0.82-1.74$ \\
\hline 37 & Orange peel & $6 / 6$ & $1.04 \pm 0.30$ & 1.04 & 1.41 & $0.63-1.47$ \\
\hline 21 & Cumin & $5 / 6$ & $0.46 \pm 0.27$ & 0.55 & 0.70 & $<\mathrm{LOQ}-0.72$ \\
\hline 36 & Nutmeg & $5 / 6$ & $0.43 \pm 0.30$ & 0.49 & 0.78 & $<\mathrm{LOQ}-0.84$ \\
\hline 53 & White mustard & $5 / 6$ & $0.38 \pm 0.30$ & 0.32 & 0.76 & $<\mathrm{LOQ}-0.79$ \\
\hline 52 & White pepper & $5 / 6$ & $0.36 \pm 0.23$ & 0.37 & 0.61 & $<\mathrm{LOQ}-0.62$ \\
\hline 7 & Black pepper & $5 / 6$ & $0.31 \pm 0.20$ & 0.37 & 0.52 & $<\mathrm{LOQ}-0.53$ \\
\hline 19 & Clove & $5 / 6$ & $0.29 \pm 0.18$ & 0.33 & 0.48 & $<\mathrm{LOQ}-0.50$ \\
\hline 30 & Lemon peel & $5 / 6$ & $0.18 \pm 0.12$ & 0.18 & 0.32 & $<\mathrm{LOQ}-0.36$ \\
\hline 46 & Sumac & $5 / 6$ & $0.14 \pm 0.08$ & 0.14 & 0.24 & $<\mathrm{LOQ}-0.26$ \\
\hline 40 & Pink pepper & $1 / 6$ & $0.11 *$ & $0.11 *$ & - & $<\mathrm{LOQ}-0.11$ \\
\hline
\end{tabular}

Note: $\mathrm{n}$ : number of samples; $\mathrm{n}+=$ positive samples $>\mathrm{LOQ}=0.10 \mathrm{ng} \mathrm{g}^{-1} ; \mathrm{SD}=$ standard deviation; 95th perc $=95 \%$ percentile; ${ }^{*}$ : the only one positive sample; left censored data: samples that contained OTA levels below LOQ were assigned a value $0 \mathrm{ng} \mathrm{g}^{-1}$ for statistical processing $\left(<\mathrm{LOQ}=0 \mathrm{ng} \mathrm{g}^{-1}\right)$ - the lower bound approach (LB) [51].

\section{Discussion}

\subsection{Comparison of OTA Results in Spices with Other Relevant Studies in the World}

To our knowledge, the set of spices analysed in this study has not been comprehensively analysed for OTA in other research papers, which makes it difficult to compare the whole dataset with the existing studies. Moreover, some types of spices included in this study such as asafoetida, black cumin, calamint, celery root, chervil, chives, citronella, dried dill tip, galangal root, green pepper, juniper, lemon peel, lovage, orange peel, pink pepper, Sichuan pepper, star anise, vanilla, white mustard, and wild garlic have never, or not recently, been analysed for the presence of OTA in other studies. The benefit of this study is certainly a positive OTA finding in some of these previously unanalysed spices such as lemon peel, orange peel, pink pepper, vanilla, and white mustard.

Therefore, we focused on evaluating our above-detection limit results in relation to the studies listed in Table 1. The comparability was possible with spices such as turmeric, liquorice, chilli, mace, ginger, cayenne pepper, sweet paprika, cumin, nutmeg, white pepper, black pepper, clove, and sumac.

To evaluate the general occurrence of OTA in given spices, we used categories from our previous study by Picková et al. [4]. These categories are based on the percentage of a total number of positive findings out of a total number of samples tested in a given spice based on recent relevant studies since 2015 . These categories are: 'no occurrence' $(0 \%)$, 'rare occurrence' (up to 5\%), 'low occurrence' (up to $25 \%$ ), 'moderate occurrence' (up to $50 \%$ ), 'high occurrence' (up to $75 \%$ ), and 'very high occurrence' (more than $75 \%$ ).

OTA in turmeric was found to be of a 'moderate occurrence'. Across all studies presented in Table 1, the average OTA concentration in turmeric was in the range of 1.89$162.00 \mathrm{ng} \mathrm{g}^{-1}[23,24,26,29-31,45]$ or was not detected at all [27]. In our study, the average concentration of $17.04 \mathrm{ng} \mathrm{g}^{-1}$ in turmeric fell within the range found in the literature. The greatest similarity of results could be observed with the average OTA concentration of $11.72 \mathrm{ng} \mathrm{g}^{-1}$ in the Polish study [45]. In our study, it was the only one spice kind with OTA concentration exceeding the EU limit of $15 \mathrm{ng} \mathrm{g}^{-1}$ [47]. Given the origin of our samples of turmeric in India, undoubtedly the largest producer of spices in the world [5], the average concentration of $17.04 \mathrm{ng} \mathrm{g}^{-1}$ does not seem to be as severe as the average concentration of $162.00 \mathrm{ng} \mathrm{g}^{-1}$ found in the Indian study [24].

OTA in liquorice was found to be of a 'moderate occurrence' [9]. Across all studies mentioned in Table 1, the average OTA concentration in liquorice was found in the range 
of $2.00-15.80 \mathrm{ng} \mathrm{g}^{-1}$ in only two studies [22,40]. In our study, liquorice with the average OTA concentration of $11.94 \mathrm{ng} \mathrm{g}^{-1}$ was within the range found in the literature and was nearly in line with the OTA concentration of $15.80 \mathrm{ng} \mathrm{g}^{-1}$ in the Czech study [40]. The EU limit of $20 \mathrm{ng} \mathrm{g}^{-1}$ for OTA was not exceeded in any of the liquorice samples [47].

OTA in chilli was found to be of a 'moderate occurrence' [4]. Across all of the studies mentioned in Table 1, the average OTA concentration was found in the range of $0.62-97.10 \mathrm{ng} \mathrm{g}^{-1}[16,17,19,21,23,25,26,29-31,33,37,39,40]$, but it was not detected in another study [32]. In our study, both average OTA concentrations of $7.50 \mathrm{ng} \mathrm{g}^{-1}$ in milled chilli and $1.43 \mathrm{ng} \mathrm{g}^{-1}$ in crushed chilli with seeds were within the range found in the literature. The average OTA concentration for milled chilli was very similar to the average OTA concentrations of $6.77 \mathrm{ng} \mathrm{g}^{-1}$ in Chinese [21], $7.70 \mathrm{ng} \mathrm{g}^{-1}$ in Lebanese [29], $7.15 \mathrm{ng} \mathrm{g}^{-1}$ in Malaysian [33], and $6.7 \mathrm{ng} \mathrm{g}^{-1}$ in Czech studies [40], while for crushed chilli with seeds to the OTA concentrations of $1.50 \mathrm{ng} \mathrm{g}^{-1}$ in the Ivory Coast study [17]. The EU limit of $20 \mathrm{ng} \mathrm{g}^{-1}$ for OTA was not exceeded in any of the chilli samples [47].

OTA in mace was found to be of a 'high occurrence' [4]. It is necessary to note that this statement was based on only one Indian study in which the average OTA concentration of $128 \mathrm{ng} \mathrm{g}^{-1}$ was found in mace [24]. In contrast, the average OTA concentration of $5.27 \mathrm{ng} \mathrm{g}^{-1}$ in mace was much lower in this study.

OTA in ginger was found to be of a 'moderate occurrence' [4]. Across all studies mentioned in Table 1, the average OTA concentration was found in the range of $0.22-82.80 \mathrm{ng} \mathrm{g}^{-1}[16-18,23]$, but it was not detected at all in other studies [29,30]. In our study, the average OTA concentration of $3.40 \mathrm{ng} \mathrm{g}^{-1}$ in ginger was in the range found in the literature. The greatest similarity was observed with the average OTA concentration of $3.75 \mathrm{ng} \mathrm{g}^{-1}$ found in the Nigerian study [18]. The EU limit of $15 \mathrm{ng} \mathrm{g}^{-1}$ for OTA was not exceeded in any of the ginger samples [47].

The average OTA concentration of $2.59 \mathrm{ng} \mathrm{g}^{-1}$ in cayenne pepper in our study was not in line with the average OTA concentration of $45.64 \mathrm{ng} \mathrm{g}^{-1}$ in the Polish study, which was the only study available for the comparison. The EU limit of $15 \mathrm{ng} \mathrm{g}^{-1}$ for OTA was not exceeded in any of the cayenne pepper samples [47].

OTA in paprika was found to be of a 'high occurrence' [4]. Across all studies mentioned in Table 1, the average OTA concentration was found in the range of 11.00$39.64 \mathrm{ng} \mathrm{g}^{-1}[19,29,30,40,42,46]$, but was not detected in another study [27]. In our study, the average OTA concentration of $2.26 \mathrm{ng} \mathrm{g}^{-1}$ in sweet paprika was not in the range found in the literature, as it was lower than the average OTA concentration of $11.00 \mathrm{ng} \mathrm{g}^{-1}$ in the Lebanese study [29]. The EU limit of $15 \mathrm{ng} \mathrm{g}^{-1}$ for OTA was not exceeded in any of the sweet paprika samples [47].

OTA in cumin was found to be of a 'low occurrence' [4]. Across all studies mentioned in Table 1, the average OTA concentration was found in the range of $0.63-20.4 \mathrm{ng} \mathrm{g}^{-1}[21,29,31,39]$, but it was not detected at all in another study [23]. In our study, the average OTA concentration of $0.46 \mathrm{ng} \mathrm{g}^{-1}$ in cumin was not within the range found in the literature as it was lower than the average OTA concentration of $0.63 \mathrm{ng} \mathrm{g}^{-1}$ in the Turkish study [39].

OTA in nutmeg was found to be of a 'very high occurrence' [4]. Across all studies mentioned in Table 1, the average OTA concentration was found in the range of $2.73-34.00 \mathrm{ng} \mathrm{g}^{-1}[29,30,40,44,45]$. In our study, the average OTA concentration of $0.43 \mathrm{ng} \mathrm{g}^{-1}$ in nutmeg was not within the range found in the literature as it was lower than the average OTA concentration of $2.73 \mathrm{ng} \mathrm{g}^{-1}$ in the Polish study [45]. The EU limit of $15 \mathrm{ng} \mathrm{g}^{-1}$ for OTA was not exceeded in any of the nutmeg samples [47].

OTA in white pepper was found to be of a 'low occurrence' [4]. Across all studies mentioned in Table 1, the average OTA was found in the range of $3.30-29.41 \mathrm{ng} \mathrm{g}^{-1}$ in only two studies $[15,45]$, but it was not detected at all in other studies [20,29-31,41]. In our study, the average OTA concentration of $0.36 \mathrm{ng} \mathrm{g}^{-1}$ in white pepper was not within the range found in the literature as it was lower than the average OTA concentration of $3.30 \mathrm{ng} \mathrm{g}^{-1}$ in the Cameroonian study [39]. The EU limit of $15 \mathrm{ng} \mathrm{g}^{-1}$ for OTA was not exceeded in any of the white pepper samples [47]. 
OTA in black pepper was found to be of a 'moderate occurrence' [4]. Across all studies mentioned in Table 2, the average OTA concentration was in the range of 0.34$155.00 \mathrm{ng} \mathrm{g}^{-1}[15,17,23-25,27,29-31,39,40,45]$ or was not detected at all $[16,20,31,41,44]$. In our study, the average OTA concentration of $0.31 \mathrm{ng} \mathrm{g}^{-1}$ in black pepper was not within the range found in the literature as it was found to be very similar, but slightly lower, than the OTA concentration of $0.0 .34 \mathrm{ng} \mathrm{g}^{-1}$ in the Turkish study [39]. The EU limit of $15 \mathrm{ng} \mathrm{g}^{-1}$ for OTA was not exceeded in any of the black pepper samples [47].

OTA in cloves was found to be of a 'none occurrence' [4], however, the study by Pickova et al. [4] dealt with only the most recent publications concerning spices since $2015[15,20,29,30]$. There has been one case of a positive finding with the average OTA concentration of $0.48 \mathrm{ng} \mathrm{g}^{-1}$ in cloves in an older Poland study [45] with which our result is in agreement as the average OTA concentration of $0.29 \mathrm{ng} \mathrm{g}^{-1}$ was in cloves.

OTA in sumac was found to be of a 'none occurrence' [4]. This statement was based on only one study in Lebanon [29]. In contrast, our study provided a positive finding of OTA in sumac with an average concentration of $0.14 \mathrm{ng} \mathrm{g}^{-1}$, which can be considered a benefit of the study.

OTA was not found in the other spice kinds included in this study. Our underdetection limit results were in line with the statement of 'none occurrence' in cases of allspice [29,30], basil [29,44], bay leaf [29], mint [29], oregano [20,29,44], parsley [29], saffron [29], and thyme [29,44]. However, there is one older Polish study that contradicts this statement and thus our results, as it presented positive results for the presence of OTA in allspice, basil, oregano, and thyme [45].

\subsection{Comparison of OTA Results in Spices with the Maximal Limits of the EU Legislation}

Commission Regulation (EC) No. 1881/2006 [47] is one of the most extensive and stringent regulations setting maximum limits for certain contaminants including mycotoxins in foodstuffs, as amended, and is suitable for comparing the results obtained, especially because of its complexity with regard to spices. Moreover, all samples were purchased in the Czech Republic, which is one of the 27 Member States of the EU, therefore only the EU limits were considered. Results showed that only one sample (50-turmeric) was contaminated with OTA at a concentration exceeding the maximal limit set by the European Union. A comparison of OTA concentrations that have been found so far in regulated spices with the maximal limits of the EU legislation is presented in Table 4.

Table 4. The concentrations of OTA in positive single-kind spices available on the Czech market and comparison with the European Union legislation.

\begin{tabular}{|c|c|c|c|}
\hline Number of Sample & Kind of Spice & $\begin{array}{l}\text { OTA Concentration }{ }^{1} \\
\left(n g g^{-1}\right)\end{array}$ & $\begin{array}{c}\text { EU Limits }^{2} \\
\left(\mathrm{ng} \mathrm{g}^{-1}\right)\end{array}$ \\
\hline 50 & Turmeric & $19.82^{3}$ & 15 \\
\hline 31 & Liquorice root & 11.94 & $20 / 80^{4}$ \\
\hline 15 & Chilli milled & 7.50 & 20 \\
\hline 27 & Ginger & 3.40 & 15 \\
\hline 11 & Cayenne pepper & 2.59 & 20 \\
\hline 47 & Sweet paprika & 2.26 & 15 \\
\hline 14 & Chilli crushed with seeds & 1.43 & 20 \\
\hline 36 & Nutmeg & 0.43 & 15 \\
\hline 52 & White pepper & 0.36 & 15 \\
\hline 7 & Black pepper & 0.31 & 15 \\
\hline 40 & Pink pepper & 0.11 & 15 \\
\hline
\end{tabular}

${ }^{1}$ Positive samples are all samples with concentrations exceeding the limit of quantification of $0.13 \mathrm{ng} \mathrm{g}{ }^{-1} ;{ }^{2} \mathrm{EU}$ limits refer to the maximum levels of OTA in spices under the European Union-Regulation No. 1881/2006 as in force [47]; ${ }^{3}$ OTA concentration exceeding the maximum permitted limit set by the European Union legislation; ${ }^{4}$ The maximum limit of OTA of $20 \mathrm{ng} \mathrm{g}^{-1}$ is valid for 'Liquorice root, an ingredient for herbal infusion'. The maximum limit of OTA of $80 \mathrm{ng} \mathrm{g}^{-1}$ is valid for 'Liquorice extract for use in food in particular beverages and confectionary' provided that it is pure and an undiluted extract is obtained whereby $1 \mathrm{~kg}$ of extract is obtained from 3 to $4 \mathrm{~kg}$ of liquorice root [47]. 


\subsection{Proposal for New Maximum Limits for OTA in the EU and FAO/WHO Codex Alimentarius}

The issue of OTA was also recently discussed in the meeting from 14 to 15 July 2021 at the Working Group for Agricultural Contaminants of the Directorate-General for Health and Food Safety, the European Commission. Amendments to the draft maximum levels for OTA in food for which there are currently no limits and the draft maximum limits for spices for which there are currently limits are currently under discussion and consideration (see Table 5) [48].

Table 5. The draft proposal of the maximum limits of OTA in spices.

\begin{tabular}{cc}
\hline Food & $\begin{array}{c}\text { Proposal of Maximum Limits } \\
\left(\mathbf{n g ~ g}^{-\mathbf{1}} \mathbf{)}\right.\end{array}$ \\
\hline All spices including dried spices except Capsicum spp. & 15 \\
Capsicum spp. (dried fruits, whole or ground, including chilli, & 20 \\
ground chilli, cayenne pepper and red pepper-paprika) \\
Mixtures of spices
\end{tabular}

The issue of OTA was also recently discussed in the report of the 14th Session of the Codex Committee on Contaminants in Foods by the Codex Alimentarius Commission (virtual) 3-7 and 13 May 2021. They discussed the maximum limits for OTA in nutmeg, dried chilli and paprika, ginger, pepper, and turmeric for comments and consideration by the Session of the Codex Committee on Contaminants in Foods in the year 2022. Maximum limits of 15-20 $\mathrm{ng} \mathrm{g}^{-1}$ for OTA in spices should be established [52].

\subsection{The Occurrence of OTA in Spices on Data by RASFF (2016-2021)}

Rapid Alert System for Food and Feed (RASFF) is a key tool ensuring food safety in the context of the EU and enables one to orientate oneself in the issue of OTA occurrence in various foods including spices. Notifications reporting the presence of OTA in spices are also valuable information for completing the idea of the current state of distributed spices. Based on the RASFF database, a total of 58 OTA notifications have been related to spices since 2016 (see Figure 3). The most prevalent notifications concerned OTA in chilli (33\%), sweet paprika powder $(21 \%)$, and nutmeg $(17 \%)$. Most OTA notifications originated in India (17\%, mostly chilli) and Indonesia (16\%, mostly nutmeg).

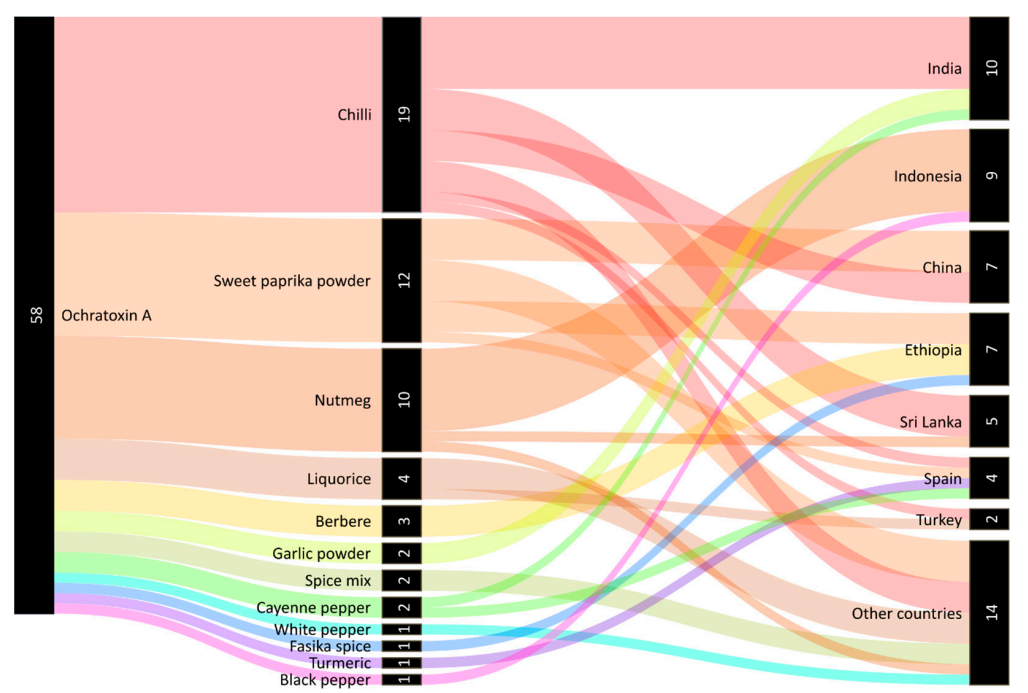

Figure 3. Notifications of ochratoxin A in spices by the Rapid Alert System for Food and Feed (RASFF) since 2016 (current to the 20 July 2021). Notes: The category 'Other countries' includes all countries of origin with only one notification for spices: Azerbaijan, Bangladesh, France, Germany, Hungary, Italy, Lebanon, Peru, Portugal, Thailand, Ukraine, the United Kingdom, and Vietnam, or notification of unknown origin. Processed according to the RASFF database [53] using The Sankey Diagram Generator online tool and vector graphics editor Inkscape 0.92. 


\section{Conclusions}

Human dietary exposure to OTA from foodstuffs is very common. Despite various effective methods for OTA mitigation and the reduction of possible health risks of OTA in foodstuffs, OTA is still a persistent problem. Although spices are not among the main sources of daily OTA intake in humans, they may contribute significantly to the co-exposure with major OTA sources such as cereals, wine, pork meat, and coffee. This may result in an additive effect and thus an increase in OTA toxicity. The significance of this study lies in the analysis of a large number of types of spices for OTA, focusing only on single-species spices, not mixtures of spices. In this study, the analysis of 54 single-kind species showed a total of $19(35 \%)$ OTA-positive spice kinds, meaning that at least one sample of a given spice kind exceeded LOQ by its concentration. Among these OTA-positive spice kinds were turmeric, liquorice root, chilli milled, mace, ginger, cayenne pepper, sweet paprika, chilli crushed with seeds, vanilla, orange peel, cumin, nutmeg, white mustard, white pepper, black pepper, clove, lemon peel, sumac, and pink pepper. This study therefore demonstrates that the Czech population is exposed to OTA through various contaminated single-kind spices available on the Czech market.

As can be seen, the spice kinds with OTA-positive findings included regulated spice kinds but also those for which regulation has not yet been set, namely mace, vanilla, orange peel, cumin, white mustard, cloves, lemon peel, sumac, and basil. Fortunately, promising discussions are already taking place in the European Commission, in which, among other things, a limit for 'all spices' has been proposed at $15 \mathrm{ng} \mathrm{g}^{-1}$, but has not been adopted yet. Taking into consideration this proposed limit for all hitherto unregulated spices, none of the analysed spice samples exceeded this value in this study.

In terms of public health protection, where food safety is an important preventive component, it is necessary to regulate various mycotoxin contents in various spices. Hence, our future research will focus not only on OTA monitoring, but also on the other mycotoxins in spices, as it will be important to verify the mycotoxin intake from this commodity.

Author Contributions: Conceptualisation, D.P., J.T., V.O. and F.M.; Methodology, D.P. and J.T.; Software, D.P. and J.T.; Validation, D.P. and J.T.; Formal analysis, D.P. and J.T.; Investigation, D.P. and J.T.; Resources, D.P. and J.T.; Data curation, D.P. and J.T.; Writing-original draft preparation, D.P.; Writing-review and editing, D.P., J.T, V.O. and F.M.; Visualisation, D.P.; Supervision, V.O. and F.M.; Project administration, D.P.; Funding acquisition, D.P. and V.O. All authors have read and agreed to the published version of the manuscript.

Funding: This research was funded by the Faculty of Science, University of Hradec Kralove, Czech Republic, under specific research project no. 2110/2021 and by Ministry of Health, Czech Republicconceptual development of research organisation ("National Institute of Public Health-NIPH, IN 75010330").

Institutional Review Board Statement: Not applicable.

Informed Consent Statement: Not applicable.

Data Availability Statement: All data are available from the corresponding authors.

Conflicts of Interest: The authors declare no conflict of interest.

\section{References}

1. Chomchalow, N. Spice Production in Asia-An Overview. AU J. Technol. 2001, 5, 1-14.

2. Sherman, P.W.; Billing, J. Darwinian Gastronomy: Why We Use Spices: Spices Taste Good Because They Are Good for Us. BioScience 1999, 49, 453-463. [CrossRef]

3. Uhl, S.R. Handbook of Spices, Seasonings, and Flavorings, 2nd ed.; CRC Press: Boca Raton, FL, USA, 2006; ISBN 978-1-4200-0436-6.

4. Pickova, D.; Ostry, V.; Malir, J.; Toman, J.; Malir, F. A Review on Mycotoxins and Microfungi in Spices in the Light of the Last Five Years. Toxins 2020, 12, 789. [CrossRef]

5. FAOSTAT. Food and Agriculture Organization of the United Nations. Available online: http://www.fao.org/faostat/en/\#data/ QC/visualize (accessed on 25 February 2020).

6. Botana, L.M.; Sainz, M.J. (Eds.) Climate Change and Mycotoxins; Walter de Gruyter GmbH: Berlin, Germany, 2015; ISBN 978-3-11-033305-3. 
7. Marroquín-Cardona, A.G.; Johnson, N.M.; Phillips, T.D.; Hayes, A.W. Mycotoxins in a Changing Global Environment-A Review. Food Chem. Toxicol. 2014, 69, 220-230. [CrossRef] [PubMed]

8. Oguntoyinbo, F.A. Safety Challenges Associated with Traditional Foods of West Africa. Food Rev. Int. 2014, 30, 338-358. [CrossRef]

9. Yogendrarajah, P.; Van Poucke, C.; De Meulenaer, B.; De Saeger, S. Development and Validation of a QuEChERS Based Liquid Chromatography Tandem Mass Spectrometry Method for the Determination of Multiple Mycotoxins in Spices. J. Chromatogr. A 2013, 1297, 1-11. [CrossRef]

10. PubChem. Available online: https://pubchem.ncbi.nlm.nih.gov/ (accessed on 7 June 2021).

11. Bhat, R.; Rai, R.V.; Karim, A.A. Mycotoxins in Food and Feed: Present Status and Future Concerns. Compr. Rev. Food Sci. Food Saf. 2010, 9, 57-81. [CrossRef] [PubMed]

12. EFSA. European Food Safety Authority Risk Assessment of Ochratoxin A in Food. EFSA J. 2020, 18, e06113. [CrossRef]

13. IARC. International Agency for Research on Cancer. IARC Monographs on the Evaluation of Carcinogenic Risks to Humans: Some Naturally Occuring Substances: Food Items and Costituents, Heterocyclic Aromatic Amines and Mycotoxins; IARC Press: Lyon, France, 1993; Volume 56, ISBN 92-832-1256-8.

14. Ostry, V.; Malir, F.; Toman, J.; Grosse, Y. Mycotoxins as Human Carcinogens-The IARC Monographs Classification. Mycotoxin Res. 2017, 33, 65-73. [CrossRef]

15. Nguegwouo, E.; Sone, L.E.; Tchuenchieu, A.; Tene, H.M.; Mounchigam, E.; Njayou, N.F.; Nama, G.M. Ochratoxin A in Black Pepper, White Pepper and Clove Sold in Yaoundé (Cameroon) Markets: Contamination Levels and Consumers' Practices Increasing Health Risk. Int. J. Food Contam. 2018, 5, 1. [CrossRef]

16. Manda, P.; Adanou, K.M.; Ardjouma, D.; Adepo, A.J.B.; Dano, D.S. Occurrence of Ochratoxin A in Spices Commercialized in Abidjan (Côte d'Ivoire). Mycotoxin Res. 2016, 32, 137-143. [CrossRef] [PubMed]

17. Fofana-Diomande, A.; Kuaou, K.; Narcisse, A.; Sory, T.; Dembele, A. Study of the Contamination of Some Spices from Côte d'Ivoire by Mycotoxins (AFB1 and OTA). J. Chem. Biol. Phys. Sci. 2019, 9, 389-399. [CrossRef]

18. Lippolis, V.; Irurhe, B.; Porricelli, A.; Cortese, M.; Schena, R.; Imafidon, T.; Oluwadun, A.; Pascale, M. Natural Co-Occurrence of Aflatoxins and Ochratoxin A in Ginger (Zingiber Officinale) from Nigeria. Food Control 2016, 73, 1061-1067. [CrossRef]

19. Motloung, L.; De Saeger, S.; De Boevre, M.; Detavernier, C.; Audenaert, K.; Adebo, O.A.; Njobeh, P.B. Study on Mycotoxin Contamination in South African Food Spices. World Mycotoxin J. 2018, 11, 401-409. [CrossRef]

20. Garcia, M.V.; Mallmann, C.A.; Copetti, M.V. Aflatoxigenic and Ochratoxigenic Fungi and Their Mycotoxins in Spices Marketed in Brazil. Food Res. Int. 2018, 106, 136-140. [CrossRef] [PubMed]

21. Zhao, X.; Yuan, Y.; Zhang, X.; Yue, T. Identification of Ochratoxin A in Chinese Spices Using HPLC Fluorescent Detectors with Immunoaffinity Column Cleanup. Food Control 2014, 46, 332-337. [CrossRef]

22. Huang, Y.; Tang, G.; Zhang, T.; Fillet, M.; Crommen, J.; Jiang, Z. Supercritical Fluid Chromatography in Traditional Chinese Medicine Analysis. J. Pharm. Biomed. Anal. 2018, 147, 65-80. [CrossRef] [PubMed]

23. Jeswal, P.; Kumar, D. Mycobiota and Natural Incidence of Aflatoxins, Ochratoxin A, and Citrinin in Indian Spices Confirmed by LC-MS/MS. Int. J. Microbiol. 2015, 2015, 242486. [CrossRef] [PubMed]

24. Jeswal, P.; Kumar, D. Natural Occurrence of Toxigenic Mycoflora and Ochratoxin A \& Aflatoxins in Commonly Used Spices from Bihar State (India). J. Environ. Sci. Toxicol. Food Technol. 2015, 9, 50-55. [CrossRef]

25. Wikandari, R.; Mayningsih, I.C.; Sari, M.D.P.; Purwandari, F.A.; Setyaningsih, W.; Rahayu, E.S.; Taherzadeh, M.J. Assessment of Microbiological Quality and Mycotoxin in Dried Chili by Morphological Identification, Molecular Detection, and Chromatography Analysis. Int. J. Environ. Res. Public Health 2020, 17, 1847. [CrossRef]

26. Jalili, M. Natural Occurrence of Ochratoxin A Contamination in Commercial Spices in Tehran. Nutr. Food Sci. Res. 2016, 3, 25-30. [CrossRef]

27. Zareshahrabadi, Z.; Bahmyari, R.; Nouraei, H.; Khodadadi, H.; Mehryar, P.; Asadian, F.; Zomorodian, K. Detection of Aflatoxin and Ochratoxin A in Spices by High-Performance Liquid Chromatography. J. Food Qual. 2020, 2020, 8858889. [CrossRef]

28. Kim, S.; Lee, S.; Nam, T.-G.; Seo, D.; Yoo, M. Comparison of a Newly Developed Liquid Chromatography with Tandem Mass Spectrometry Method and Enzyme-Linked Immunosorbent Assay for Detection of Multiple Mycotoxins in Red Pepper Powder. J. Food Prot. 2017, 80, 1347-1354. [CrossRef] [PubMed]

29. El Darra, N.; Gambacorta, L.; Solfrizzo, M. Multimycotoxins Occurrence in Spices and Herbs Commercialized in Lebanon. Food Control. 2019, 95, 63-70. [CrossRef]

30. Al Ayoubi, M.; Solfrizzo, M.; Gambacorta, L.; Watson, I.; El Darra, N. Risk of Exposure to Aflatoxin B1, Ochratoxin A, and Fumonisin B1 from Spices Used Routinely in Lebanese Cooking. Food Chem. Toxicol. 2021, 147, 111895. [CrossRef] [PubMed]

31. Ali, N.; Hashim, N.H.; Shuib, N.S. Natural Occurrence of Aflatoxins and Ochratoxin A in Processed Spices Marketed in Malaysia. Food Addit. Contam. Part A Chem. Anal. Control Expo. Risk Assess. 2015, 32, 518-532. [CrossRef]

32. Alsharif, A.M.A.; Choo, Y.-M.; Tan, G.-H. Detection of Five Mycotoxins in Different Food Matrices in the Malaysian Market by Using Validated Liquid Chromatography Electrospray Ionization Triple Quadrupole Mass Spectrometry. Toxins 2019, 11, 196. [CrossRef]

33. Jalili, M.; Jinap, S. Natural Occurrence of Aflatoxins and Ochratoxin A in Commercial Dried Chili. Food Control 2012, 24, 160-164. [CrossRef]

34. Iqbal, S.; Rafique Asi, M.; Zuber, M.; Akhtar, J.; Saif, M. Natural Occurrence of Aflatoxins and Ochratoxin A in Commercial Chilli and Chilli Sauce Samples. Food Control 2013, 30, 621-625. [CrossRef] 
35. Iqbal, S.Z.; Asi, M.R.; Mehmood, Z.; Mumtaz, A.; Malik, N. Survey of Aflatoxins and Ochratoxin A in Retail Market Chilies and Chili Sauce Samples. Food Control 2017, 81, 218-223. [CrossRef]

36. Gherbawy, Y.A.; Shebany, Y.M. Mycobiota, Total Aflatoxins and Ochratoxin A of Cardamom Pods. Food Sci. Technol. Res. 2018, 24, 87-96. [CrossRef]

37. Yogendrarajah, P.; Jacxsens, L.; De Saeger, S.; De Meulenaer, B. Co-Occurrence of Multiple Mycotoxins in Dry Chilli (Capsicum Annum, L.) Samples from the Markets of Sri Lanka and Belgium. Food Control 2014, 46, 26-34. [CrossRef]

38. Jacxsens, L.; Pratheeb, Y.; Meulenaer, B. Risk Assessment of Mycotoxins and Predictive Mycology in Sri Lankan Spices: Chilli and Pepper. Procedia Food Sci. 2016, 6, 326-330. [CrossRef]

39. Ozbey, F.; Kabak, B. Natural Co-Occurrence of Aflatoxins and Ochratoxin A in Spices. Food Control 2012, 28, 354-361. [CrossRef]

40. Ostry, V.; Malir, F.; Dofkova, M.; Skarkova, J.; Pfohl-Leszkowicz, A.; Ruprich, J. Ochratoxin A Dietary Exposure of Ten Population Groups in the Czech Republic: Comparison with Data over the World. Toxins 2015, 7, 3608-3635. [CrossRef] [PubMed]

41. Fazekas, B.; Tar, A.; Kovács, M. Aflatoxin and Ochratoxin a Content of Spices in Hungary. Food Addit. Contam. 2005, 22, 856-863. [CrossRef] [PubMed]

42. Gambacorta, L.; Magistà, D.; Perrone, G.; Murgolo, S.; Logrieco, A.F.; Solfrizzo, M. Co-Occurrence of Toxigenic Moulds, Aflatoxins, Ochratoxin A, Fusarium and Alternaria Mycotoxins in Fresh Sweet Peppers (Capsicum Annuum) and Their Processed Products. World Mycotoxin J. 2018, 11, 159-174. [CrossRef]

43. Prelle, A.; Spadaro, D.; Garibaldi, A.; Gullino, M.L. Co-Occurrence of Aflatoxins and Ochratoxin A in Spices Commercialized in Italy. Food Control 2014, 39, 192-197. [CrossRef]

44. Reinholds, I.; Pugajeva, I.; Bavrins, K.; Kuckovska, G.; Bartkevics, V. Mycotoxins, Pesticides and Toxic Metals in Commercial Spices and Herbs. Food Addit. Contam. Part B 2016, 10, 5-14. [CrossRef] [PubMed]

45. Waskiewicz, A.; Beszterda, M.; Bocianowski, J.; Golinski, P. Natural Occurrence of Fumonisins and Ochratoxin A in Some Herbs and Spices Commercialized in Poland Analyzed by UPLC-MS/MS Method. Food Microbiol. 2013, 36, 426-431. [CrossRef]

46. Santos, L.; Marín, S.; Sanchis, V.; Ramos, A.J. Co-Occurrence of Aflatoxins, Ochratoxin A and Zearalenone in Capsicum Powder Samples Available on the Spanish Market. Food Chem. 2010, 122, 826-830. [CrossRef]

47. European Commission. Commission Regulation (EC) No. 1881/2006 of 19 December 2006 Setting Maximum Levels for Certain Contaminants in Foodstuffs. Off. J. Eur. Union 2006, L364, 5-24.

48. MoA. The Ministry of Agriculture of the Czech Republic: Current Discussed Topics in the Field of Contaminants in FoodJuly 2021. Available online: https://www.bezpecnostpotravin.cz/aktualni-diskutovana-temata-v-oblasti-kontaminantu-vpotravinach-cervenec-2021.aspx (accessed on 15 May 2021).

49. Zimmerli, B.; Dick, R. Determination of Ochratoxin A at the Ppt Level in Human Blood, Serum, Milk and Some Foodstuffs by High-Performance Liquid Chromatography with Enhanced Fluorescence Detection and Immunoaffinity Column Cleanup: Methodology and Swiss Data. J. Chromatogr. B Biomed. Sci. Appl. 1995, 666, 85-99. [CrossRef]

50. European Commission. Commision Regulation (EC) No 401/2006 of 23 February 2006 Lying down the Methods of Sampling and Analysis for the Official Control of the Levels of Mycotoxins in Foodstuffs. Off. J. Eur. Union 2006, L70, 1-42.

51. EFSA, European Food Safety Authority. Management of Left-Censored Data in Dietary Exposure Assessment of Chemical Substances. EFSA J. 2010, 8, 1-96. [CrossRef]

52. FAO/WHO. Joint FAO/WHO Food Standards Programme. In Proceedings of the Codex Alimentarius Commission 44th Session, Geneva, Switzerland, 8-13 November 2021; Report of the 14th Session of the Codex Committee on Contaminants in Foods (Virtual) 3-7 and 13 May 2021. Available online: https:/ /www.fao.org/fao-who-codexalimentarius/sh-proxy/fr/?lnk=1\& url=https \%253A \%252F\%252Fworkspace.fao.org\%252Fsites\%252Fcodex\%252FMeetings \%252FCX-735-14\%252FREPORT\%25 2FFinalReport\%252FREP21_CFe.pdf (accessed on 20 July 2021).

53. RASFF. Rapid Alert System for Food and Feed Portal Database. Available online: https://webgate.ec.europa.eu/rasff-window / portal/ (accessed on 20 July 2021). 